\title{
Digitalis induced paroxysmal atrial tachycardia with AV block
}

\author{
B. L. Agarwal and B. V. Agrawal \\ From the Department of Medicine, M.L.N. Medical College, Allahabad, India
}

Twenty-four instances of digitalis induced paroxysmal atrial tachycardia with block in 20 inpatients are described. Cases of cor pulmonale with hypoxia were more prone to develop this arrhythmia. Electrocardiographic features consisted of an atrial rate ranging from IIS to 230 a minute and an altered configuration of the $P$ wave which was diminutive in nearly half the cases. The block at the AV node was commonly varying or 2:I.

Four patients (20\%) died within 12 hours of the recognition of this abnormality. PAT with block is ranked second to ventricular tachycardia in its malignancy.

Unlike paroxysmal atrial tachycardia of 'normal' hearts, paroxysmal atrial tachycardia with AV block (PAT with block) is commonly precipitated by digitalis in excess, with or without potassium depleting diuretics. It was originally reported by Lewis (1909) from a polygraphic recording of jugular and radial pulses. The causative relation to digitalis was first suggested by Mackenzie (I9II) and was further clarified by Heyl in 1932 . After a lapse of 22 years attention was redrawn to this arrhythmia by Lown and Levine (1954) by their extensive clinical and experimental work. Recent studies indicate that PAT with block is a common arrhythmia and is being increasingly recognized (Lown and Levine, 1958; Hejtmancik, Herrmann, and Wright, 1958; Goldberg et al., 1960; Harris, Julian, and Oliver, 1960; Oram, Resnekov, and Davies, 1960; Burton, 1962; Wahi et al., 1966). The largest series (II2 episodes in 88 patients) is that of Lown and Levine (1958).

In this study examples of PAT with block were encountered in patients on digitalis. Some of the clinical and electrocardiographic features of this arrhythmia are presented.

\section{Material and methods}

A total of 292 patients was put on digitalis in a period of 18 months from January 1968 to June 1969. Only one proprietary brand of digitalis glycoside (Lanoxin) was used both orally and parenterally throughout this period. A I2-lead reference electrocardiogram was taken immediately on admission which was often before the

Received 25 May 1971. patient had received any digitalis. During the period of observation, tracings consisting of long rhythm strips of leads II, aVF, and VI were frequently recorded. If $P$ waves were not easily identifiable in routine leads a special bipolar chest lead (S5) with the right arm electrode over the manubrium and the left arm electrode over the right fifth interspace was used. The response to carotid sinus massage was continuously monitored.

The genuineness of an arrhythmia as a toxic manifestation in a patient on digitalis is always suspect as it may also be the result of underlying heart disease. Fairly rigid criteria were, therefore, applied before PAT with block was attributed to overdosage of the glycoside.

(I) Intake of adequate digitalizing or maintenance dose of the drug with or without potassium depleting diuretics in the immediate past.

(2) Abolition of the ectopic rhythm after withdrawal of digitalis and institution of corrective therapy.

(3) Presence of concurrent or preceding manifestations of digitalis intoxication, namely gastrointestinal symptoms, ventricular bigeminy, various grades of AV block, etc.

Digitalis effect in the electrocardiogram was only considered a corroborative evidence of digitalis intake.

\section{Results}

Cardiac arrhythmias and conduction defects directly attributable to digitalis poisoning were recorded in $105(36 \%)$ out of $292 \mathrm{pa}-$ tients receiving this drug (Agarwal and Agrawal, 1970). There were 24 instances of PAT with block in 20 patients, comprising 19 per cent of the toxic cases. 
TABLE Clinical and therapeutic details of patients with digitoxic PAT with block

\begin{tabular}{|c|c|c|c|c|c|c|c|c|}
\hline $\begin{array}{l}\text { Case } \\
\text { No. }\end{array}$ & $\begin{array}{l}\text { Age } \\
(y r)\end{array}$ & Heart disease & $\begin{array}{l}\text { Associated } \\
\text { complications }\end{array}$ & $\begin{array}{l}\text { Lanoxin in the } \\
\text { immediate pre- } \\
\text { ceding period }\end{array}$ & Diuretics & $\begin{array}{l}\text { Toxic manifesta- } \\
\text { tions preceding } \\
P A T \text { with block }\end{array}$ & $\begin{array}{l}\text { Treatment } \\
\text { (besides } \\
\text { withdrawal } \\
\text { of digitalis) }\end{array}$ & $\begin{array}{l}\text { Return to } \\
\text { sinus } \\
\text { rhythm }\end{array}$ \\
\hline $\mathbf{I}$ & 25 & $\begin{array}{l}\text { Rheumatic heart } \\
\text { disease }\end{array}$ & $\begin{array}{l}\text { Acute bron- } \\
\text { chitis }\end{array}$ & $3.50 \mathrm{mg}$ in $3 \mathrm{dy}$ & $\mathrm{Nil}$ & $\begin{array}{l}\text { Headache, nausea, } \\
\text { and vomiting; } \\
\text { atrial fibrillation }\end{array}$ & Nil & $5 \mathrm{dy}$ \\
\hline 2 & 40 & $\begin{array}{l}\text { Rheumatic heart } \\
\text { disease }\end{array}$ & $\begin{array}{l}\text { Acute bron- } \\
\text { chitis }\end{array}$ & $\begin{array}{l}0.37 \mathrm{mg} \text { daily } \\
\text { for } 8 \mathrm{dy}\end{array}$ & $\begin{array}{l}\text { Frusemide } 40 \mathrm{mg} \\
\text { daily }\end{array}$ & Atrial fibrillation & Nil & $2 d y$ \\
\hline 3 & I0 & $\begin{array}{l}\text { Rheumatic heart } \\
\text { disease }\end{array}$ & $\begin{array}{l}\text { Acute rheumatic } \\
\text { carditis }\end{array}$ & $\mathrm{I} \cdot 75 \mathrm{mg}$ in $3 \mathrm{dy}$ & $\begin{array}{l}\text { Hydrochlorothiazide } \\
25 \mathrm{mg} \text { daily }\end{array}$ & $\begin{array}{l}\text { Anorexia, nausea, } \\
\text { and vomiting }\end{array}$ & $\begin{array}{r}\text { Potassium } \\
\text { chloride }\end{array}$ & $3 \mathrm{dy}$ \\
\hline 4 & 50 & $\begin{array}{l}\text { Severe anaemia } \\
\text { with CCF }\end{array}$ & $\mathrm{Nil}$ & $3 \mathrm{mg}$ in $3 \mathrm{dy}$ & $\begin{array}{l}\text { Frusemide } 40 \mathrm{mg} \\
\text { daily }\end{array}$ & $\begin{array}{l}\text { Anorexia, nausea, } \\
\text { and vomiting }\end{array}$ & $\mathrm{Nil}$ & $3 \mathrm{dy}$ \\
\hline 5 & 50 & Cor pulmonale & $\begin{array}{l}\text { Carbon dioxide } \\
\text { narcosis }\end{array}$ & $\begin{array}{l}0.25-0.50 \mathrm{mg} \\
\text { for one mth } \\
\text { (maintenance } \\
\text { dose) }\end{array}$ & $\begin{array}{l}\text { Mersalyl } 2 \mathrm{ml} \\
\text { biweekly }\end{array}$ & Nil & $\begin{array}{r}\text { Potassium } \\
\text { chloride }\end{array}$ & $7 \mathrm{dy}$ \\
\hline 6 & 20 & $\begin{array}{l}\text { Rheumatic heart } \\
\text { disease }\end{array}$ & Nil & $3.50 \mathrm{mg}$ in $4 \mathrm{dy}$ & $\begin{array}{l}\text { Hydroflumethiazide } \\
50 \mathrm{mg} \text { daily }\end{array}$ & Vomiting & $\begin{array}{r}\text { Potassium } \\
\text { chloride }\end{array}$ & $3 \mathrm{dy}$ \\
\hline 7 & 40 & Cor pulmonale & Nil & $3.75 \mathrm{mg}$ in $5 \mathrm{dy}$ & $\begin{array}{l}\text { Mersalyl } 2 \mathrm{ml} \\
\text { biweekly }\end{array}$ & $\begin{array}{l}\text { Nausea and } \\
\text { vomiting }\end{array}$ & $\begin{array}{r}\text { Potassium } \\
\text { chloride }\end{array}$ & $4 d y$ \\
\hline 8 & 55 & $\begin{array}{l}\text { Constrictive } \\
\text { pericarditis } \\
\text { (postoperative) }\end{array}$ & Nil & $\begin{array}{l}0.37 \mathrm{mg} \text { daily } \\
\text { for } 15 \text { dy } \\
\text { (maintenance } \\
\text { dose) }+0.5 \mathrm{mg} \\
\text { intravenously } \\
\text { postoperatively }\end{array}$ & $\begin{array}{l}\text { Hydrochlorothiazide } \\
50 \mathrm{mg} \text { on alternate } \\
\text { dy }\end{array}$ & Nil & - & $\begin{array}{c}\text { Died after } \\
\text { one hr }\end{array}$ \\
\hline 9 & 30 & $\begin{array}{l}\text { Rheumatic heart } \\
\text { disease }\end{array}$ & $\mathrm{Nil}$ & $2.5 \mathrm{mg}$ in $3 \mathrm{dy}$ & $\begin{array}{l}\text { Hydrochlorothiazide } \\
25 \mathrm{mg} \text { on alternate } \\
\text { dy }\end{array}$ & Nil & Nil & $2 \mathrm{dy}$ \\
\hline Io & 15 & $\begin{array}{l}\text { Rheumatic heart } \\
\text { disease }\end{array}$ & Nil & $\begin{array}{l}0.37 \mathrm{mg} \text { daily } \\
\text { for Io dy } \\
\text { (maintenance } \\
\text { dose) }+0.25 \mathrm{mg} \\
\text { intravenously } \\
\text { after valvotomy }\end{array}$ & $\begin{array}{l}\text { Hydrochlorothiazide } \\
25 \mathrm{mg} \text { on alternate } \\
\text { dy } \\
\text { y }\end{array}$ & $\mathrm{Nil}$ & Nil & $6 \mathrm{hr}$ \\
\hline I I & 65 & Cor pulmonale & Nil & $3.50 \mathrm{mg}$ in $6 \mathrm{dy}$ & $\begin{array}{l}\text { Hydrochlorothiazide } \\
50 \mathrm{mg} \text { once daily }\end{array}$ & Nil & $\begin{array}{r}\text { Potassium } \\
\text { chloride }\end{array}$ & $3 \mathrm{dy}$ \\
\hline 12 & 66 & $\begin{array}{l}\text { Hypertension } \\
\text { with left } \\
\text { ventricular } \\
\text { failure }\end{array}$ & $\begin{array}{l}\text { Pre-existing } \\
\text { left bundle- } \\
\text { branch block }\end{array}$ & $2.75 \mathrm{mg}$ in $2 \mathrm{dy}$ & $\begin{array}{l}\text { Frusemide } 40 \mathrm{mg} \\
\text { once daily }\end{array}$ & Nil & $\begin{array}{r}\text { Potassium } \\
\text { chloride }\end{array}$ & $4 d y$ \\
\hline 13 & 50 & Cor pulmonale & $\mathrm{Nil}$ & $2.75 \mathrm{mg}$ in $3 \mathrm{dy}$ & $\begin{array}{c}\text { Mersalyl } 2 \mathrm{ml} \\
\text { biweekly }\end{array}$ & Nil & $\begin{array}{r}\text { Potassium } \\
\text { chloride }\end{array}$ & $3 \mathrm{dy}$ \\
\hline 14 & 65 & Cor pulmonale & $\begin{array}{l}\text { Central } \\
\text { cyanosis }++\end{array}$ & $\begin{array}{l}0.50 \mathrm{mg} \text { for } \\
20 \mathrm{dy} \\
\text { (maintenance } \\
\text { dose) }\end{array}$ & $\begin{array}{l}\text { Hydrochlorothiazide } \\
25 \mathrm{mg} \text { on alternate } \\
\text { dy }\end{array}$ & Vomiting & Nil & $3 \mathrm{dy}$ \\
\hline 15 & 8 & $\begin{array}{l}\text { Rheumatic heart } \\
\text { disease }\end{array}$ & Nil & $2 \mathrm{mg}$ in $3 \mathrm{dy}$ & $\begin{array}{l}\text { Hydrochlorothiazide } \\
50 \mathrm{mg} \text { on } \\
\text { alternate dy }\end{array}$ & Nil & Nil & Io $\mathrm{hr}$ \\
\hline 16 & 22 & $\begin{array}{l}\text { Rheumatic heart } \\
\text { disease }\end{array}$ & Nil & $\begin{array}{l}0.5 \mathrm{mg} \text { for a } \\
\text { mth (main- } \\
\text { tenance dose) }\end{array}$ & $\begin{array}{l}\text { Hydrochlorothiazide } \\
50 \mathrm{mg} \text { on } \\
\text { alternate dy }\end{array}$ & Nil & $\begin{array}{r}\text { Potassium } \\
\text { chloride }\end{array}$ & $3 \mathrm{dy}$ \\
\hline 17 & 12 & Cardiomyopathy & $\begin{array}{l}\text { Pulmonary } \\
\text { tuberculosis }\end{array}$ & $\mathrm{r} \cdot 75 \mathrm{mg}$ in $3 \mathrm{dy}$ & $\begin{array}{l}\text { Hydrochlorothiazide } \\
50 \mathrm{mg} \text { daily }\end{array}$ & Nil & $\begin{array}{r}\text { Potassium } \\
\text { chloride }\end{array}$ & $\begin{array}{l}\text { Died after } \\
6 \mathrm{hr}\end{array}$ \\
\hline 18 & 40 & $\begin{array}{l}\text { Cor pulmonale } \\
\text { with CCF }\end{array}$ & $\begin{array}{l}\text { Carbon dioxide } \\
\text { narcosis }\end{array}$ & $2.25 \mathrm{mg}$ in $4 \mathrm{dy}$ & $\begin{array}{l}\text { Hydrochlorothiazide } \\
50 \mathrm{mg} \text { once daily }\end{array}$ & $\begin{array}{l}\text { Anorexia, nausea, } \\
\text { and vomiting }\end{array}$ & $\begin{array}{r}\text { Potassium } \\
\text { chloride }\end{array}$ & $\begin{array}{l}\text { Died after } \\
\text { I2 hr }\end{array}$ \\
\hline 19 & 35 & $\begin{array}{l}\text { Cor pulmonale } \\
\text { with CCF }\end{array}$ & Central cyanosis & $3.25 \mathrm{mg}$ in $5 \mathrm{dy}$ & $\begin{array}{l}\text { Hydrochlorothiazide } \\
50 \mathrm{mg} \text { once daily }\end{array}$ & Nil & $\begin{array}{r}\text { Potassium } \\
\text { chloride }\end{array}$ & $2 d y$ \\
\hline 20 & $6 r$ & $\begin{array}{l}\text { Myocardial in- } \\
\text { farction with } \\
\text { left ventricular } \\
\text { failure }\end{array}$ & Nil & $2.75 \mathrm{mg}$ in $2 \mathrm{dy}$ & $\begin{array}{c}\text { Frusemide } 80 \mathrm{mg} \\
\text { daily for } 2 \mathrm{dy}\end{array}$ & Nil & $\begin{array}{r}\text { Potassium } \\
\text { chloride }\end{array}$ & $\begin{array}{l}\text { Died after } \\
4 \mathrm{hr}\end{array}$ \\
\hline
\end{tabular}

$\mathrm{CCF}=$ Congestive cardiac failure. 
Details of these patients as to age, type of heart disease, digitalis dosage, diuretics, and therapy are given in the Table. The nature of the cardiac disorders of these patients was roughly representative of the distribution of various types of heart disease seen in patients in hospital except for cor pulmonale which was proportionately more. Four out of 7 suffering from pulmonary heart disease had central cyanosis or fully fledged manifestations of carbon dioxide narcosis. All patients were in congestive heart failure except one with constrictive pericarditis to whom the drug was given erroneously. The initial digitalizing or maintenance dosages of the glycoside were well within the recommended limits. Four patients developed this arrhythmia during low maintenance therapy.

Sinus rhythm was restored in 16 survivors in 6 hours to 7 days after withdrawal of the drug, with or without administration of potassium chloride. Four patients died soon after this abnormal rhythm was recorded (Cases 8, 17, 18, and 20).

\section{Discussion}

A digitoxic cardiac arrhythmia can be suspected at the bedside if it is preceded or accompanied by familiar symptoms of overdosage of the drug or tell-tale pulsus bigeminus. PAT with block may, however, develop without any premonitory symptoms (Lown and Levine, 1954). In 60 per cent of cases in this series (Table) there were no warning symptoms or signs. Strong presumptive evidence of its occurrence is often manifested in a paradoxical tachycardia or aggravation of heart failure in spite of adequate digitalis dosage. Even then a physician has to lean heavily on frequent electrocardiographic monitoring for early recognition.

In the published series of digitalis induced cardiac arrhythmias the relative incidence of PAT with block is variable (Herrmann, Decherd, and McKinlay, 1944; Flaxman, 1948; Crouch, Herrmann, and Hejtmancik, 1956; Shrager, 1957; von Capeller, Copeland, and Stern, 1959; Rodensky and Wasserman, 1961; Dreifus et al., 1963; Dubnow and Burchell, 1965; Chung, 1970). On pooling the results of the above reports the mean percentage of this arrhythmia is 14 per cent. Our observation of 19 per cent is a little higher than the pooled result.

It was not surprising to find a high incidence of toxic arrhythmia in cor pulmonale as compared to other forms of cardiac lesions in this series. Significant depletion of body potassium has been reported in hypoxia associated with chronic pulmonary insuffi- ciency by Baum et al. (1959). They have presented electrocardiographic evidence of sensitivity to a test dose of acetylstrophanthidin. Frequent association of PAT with block in chronic pulmonary heart disease has also been the subject of other reports (Goldberg et al., 1960; Burton, 1962).

Electrocardiographic features Diagnosis of PAT with block rests essentially on the

FIG. I (Case I6) PAT with latent $A V$ block. The strip in the first row shows sinus conducted beats before administration of digitalis. PAT I:I with latent block is seen in the second strip. The block has increased after carotid massage in the third strip (increased $P R$ interval). After further carotid sinus pressure Wenckebach block developed (last strip). $P$ waves are marked with a dot.

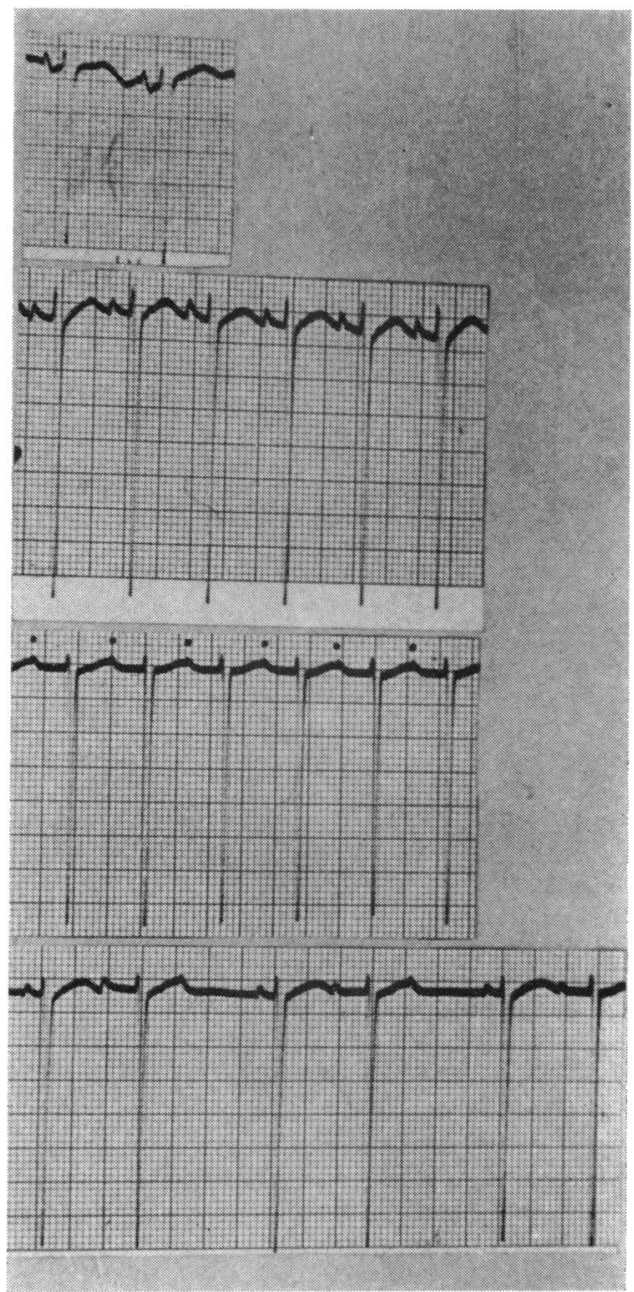


electrocardiogram. The distinctive features have been clearly laid down by Lown and Levine (1958) and are a usual atrial rate of I40-220 a minute, a baseline which is isoelectric between atrial complexes, an atrioventricular block latent or overt, and an altered but commonly upright $\mathbf{P}$ wave in standard leads II, III, and aVF.

\section{Atrial complex}

The contour of the $P$ wave is nearly always altered in at least one of the leads, II, III, aVF, or right praecordial leads. We did not confine ourselves to examination in lead II alone. In at least one patient (Case 9) the $P$ waves were unchanged in lead II, III, and aVF and there was an unequivocal change in its morphology in VI betraying the ectopic nature of the pacemaker. Upright sinus P waves of lead II became diminutive in II, peaked in 4, bifid in 3 , inverted in 4 , and remained unaffected in the other 2. The pathognomonic diminutive $\mathbf{P}$ waves (including 3 examples of bifid $P$ ) were thus seen in a little over half the cases $(58 \%)$ as compared to 75 per cent cases of Lown and Levine (1958) and El-Sherif (1970).

A variation in the PP cycle length, if present, is considered to be diagnostic of digitalis induced PAT with block and had been noted by most workers in one-third to one-half of their cases (Lown, Wyatt, and Levine, 1960; Phillips et al., 1966; El-Sherif, 1970). It has been attributed to a negative chronotropic effect of ventricular systole and is termed ventriculophasic arrhythmia by Rosenbaum and Lepeschkin (1955). It ranged from 0.02 $\mathrm{sec}$ to $0.06 \mathrm{sec}$ in 9 out of 19 instances where the block was $2: 1$ or more.

The atrial rate varied from II5 to 230 a minute in this series, the average being 170 . Rates as low as 72 (El-Sherif, 1970) and as

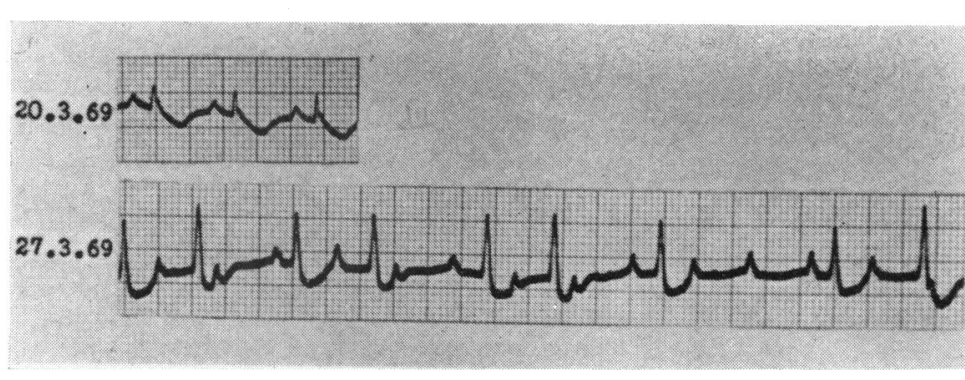

FIG. 2 (Case 14) PAT with varying $A V$

block ( $I: I$ response with prolonged $P R$

interval, $2: 1$ and 3:I). The morphology

of $P$ waves is different from that of the

sinus pacemaker (first strip).

high as 400 (Simonson and Berman, 195I) have been recorded.

\section{$A V$ response}

The block by definition is an essential criteria of this dysrhythmia. All types of delay in conduction from a latent block to 12 : I were noted. The former was unmasked after carotid sinus pressure (Fig. I, Case I6). The common 2:I response was seen in 8 cases but even more often ( 9 cases) the block was changing in the same strip (Fig. 2, Case I4).

\section{Concurrent electrocardiographic abnormalities}

Accompaniment of other digitoxic stigmata in the tracing establishes the toxic nature of the arrhythmia, as stated earlier. Four patients had ventricular bigeminy, one of whom had in addition a salvo of 3 ventricular ectopic beats (Fig. 3, Case 18). One of the patients (Case 17) had nodal rhythm with AV dissociation (Fig. 4) and another frequent nodal extrasystole.

FIG. 3 (Case 18) PAT with 2:I response, ventricular bigeminy, and a salvo of 3 ventricular extrasystole. Ectopic beats are multiform and multifocal.

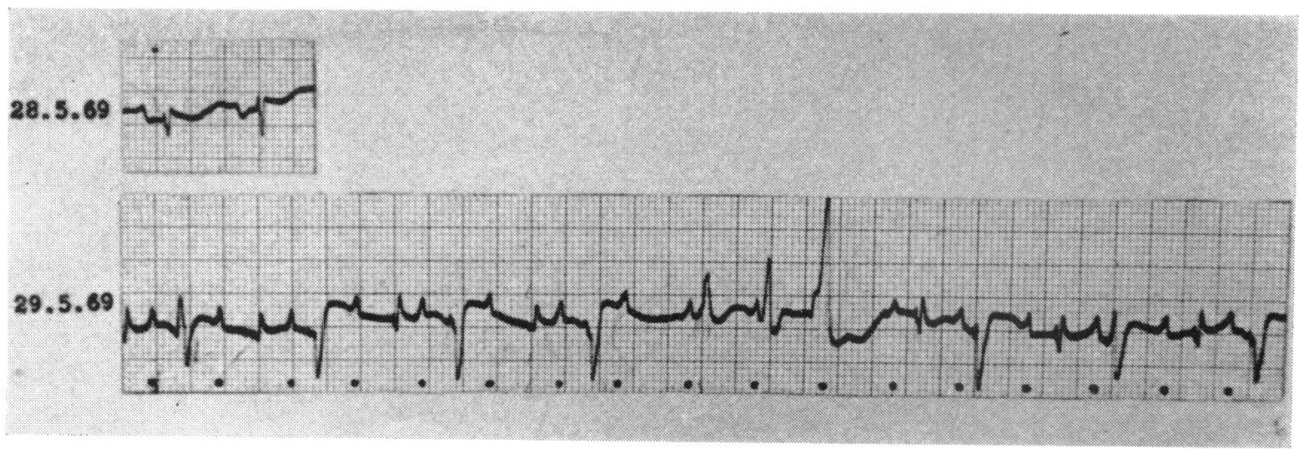




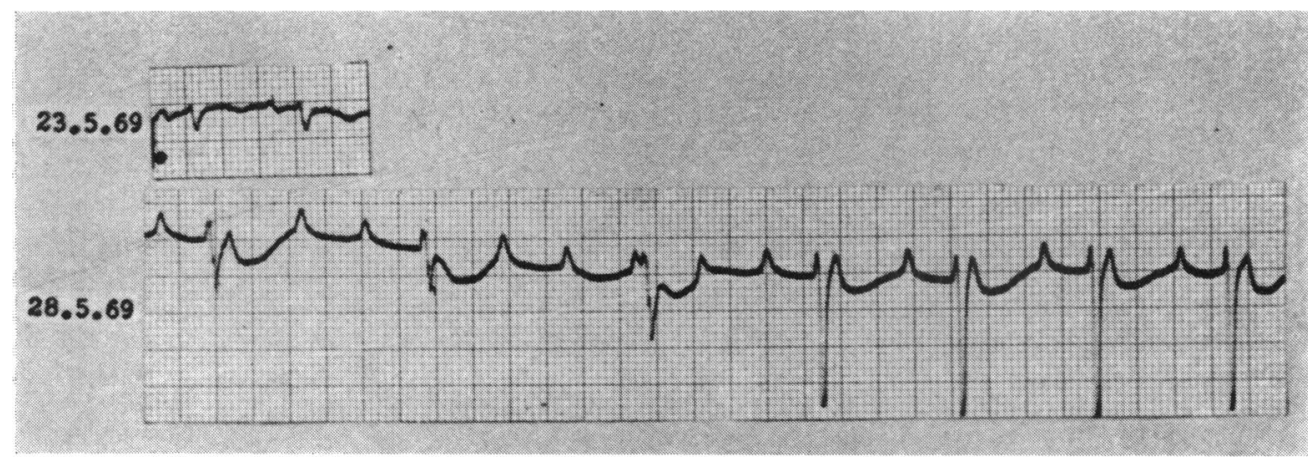

FIG. 4 (Case 17) The first 3 ventricular complexes of the second strip are equidistant and aberrant (nodal rhythm with $A V$ dissociation). The latter part of the strip shows PAT with 2:I block and ventriculophasic arrhythmia of 0.02 sec.

Diagnosis Even with rigid diagnostic criteria, difficulty may arise in distinguishing it from a number of conditions. In a case with $\mathrm{I}: \mathrm{I}$ response it may be mistaken for sinus tachycardia if an earlier tracing of a sinus rhythm is not available to compare the altered morphology of $P$ waves. A classical PAT with 2: I block may be dismissed as sinus rhythm if the first $P$ is superimposed on $Q R S$ or $T$ of the preceding complex. For the same reasons, nodal rhythm or tachycardia can be simulated in $I: I$ conduction. Carotid massage by increasing the AV block and unmasking the $P$ will expose the real nature of the arrhythmia. Oesophageal leads or percutaneous right atrial lead $\left(\mathrm{S}_{5}\right)$ can also bring to light the culprit $\mathbf{P}$ but that is hardly ever done simultaneously with the standard leads. If the $P$ waves are not identifiable and the block variable it can mimic atrial fibrillation (Fig. 5, Case 4). Conventional paroxysmal atrial tachycardia can be easily distinguished from the toxic one by the history, response to vagal stimulation by carotid sinus compression, and constant cycle lengths. It is important not to mistake PAT with block for atrial flutter as digitalis is 'poison' for the former and 'food' for the latter. The distinction is easy in an average case with $P$ inscribed at a rate faster than 250 and a saw-tooth baseline in even one lead. In borderline cases where the rate varies between 200 and 250 , real difficulty in diagnosis may arise. History of digitalis intake in excess, its stigmata in the form of ventricular premature beats if present, and finally response to potassium chloride will help to unravel the mystery.

Prognosis According to Lown and Levine (1958), PAT with block carries a grave prognosis as 60 per cent of the lethal dose is likely to have been received by the time it is recorded. Fifty-eight per cent of their patients, most of whom had severe forms of heart disease, died shortly after this arrhythmia. The reported mortality figures are fairly

FIG. 5 (Case 4) PAT with varying $A V$ block in lead II simulates atrial fibrillation as diminutive $P$ waves are barely discernible. The block is $2: I$ in $a V F$.

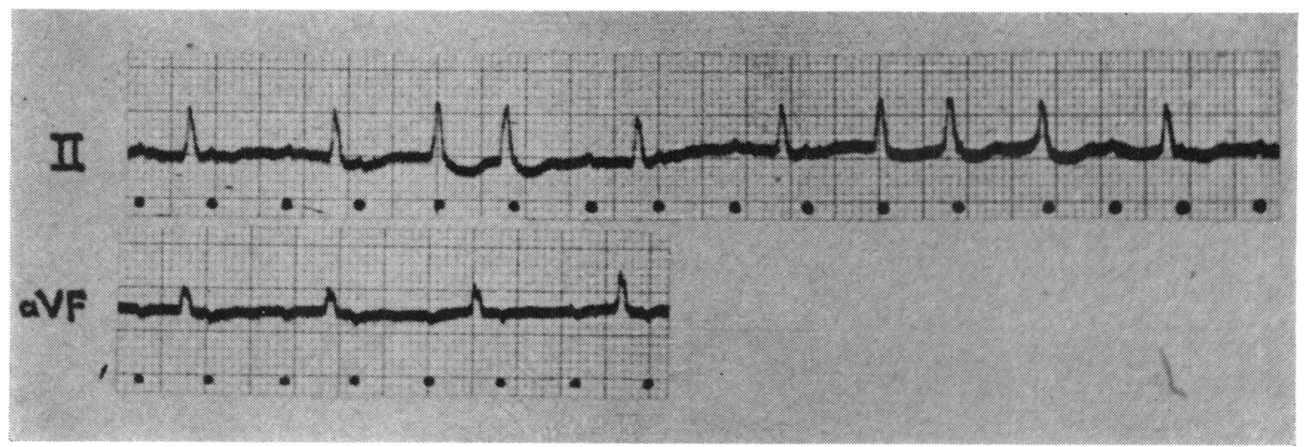


high and range from 28 per cent (Freiermuth and Jick, 1958) to 58 per cent (Nadas, Rudolph, and Reinhold, 1953). The case fatality of a series depends on the seriousness of heart disease of its constituents, period of observation, and time taken in detection of this arrhythmia. Of our 20 cases, only 4 died $(20 \%)$. The number of younger patients with a relatively milder form of heart disease (8 rheumatic hearts) was probably responsible for the lower death rate in our series. Lown and Levine (1958) had themselves stated that if PAT was recognized early and appropriate measures taken, the mortality was 35 per cent, but if digitalis was continued or increased it was doubled. Observations of El-Sherif (1970) are revealing in this respect: there was an overall mortality of $\mathbf{2 2}$ per cent in his series of digitalis induced supraventricular tachycardia but in those in whom it was detected early and specific treatment given it was reduced to 9 per cent. Even more illustrative is the report of Dreifus et al. (1963) who noted a mortality of 100 per cent in 7 cases of PAT with block where its sinister nature was not recognized and digitalis continued, while in the other 16 where digitalis was stopped, with or without corrective therapy, only one died. In our opinion PAT with block should be considered second to ventricular tachycardia in its malignancy.

We are grateful to Professor V. N. Mital, Dr. H. S. Mital, Dr. Prem Kumar, Dr. R. K. Agarwal, and Dr. D. K. Nigam of Medical College Hospital for permitting us to study the cases under their care.

\section{References}

Agarwal, B. L., and Agrawal, B. V. (1970). Digitalis intoxication in hospital practice: a report of 149 cases. Abstracts VI World Congress of Cardiology, p. 60. London.

Baum, G. L., Dick, M. M., Blum, A., Kaupe, A., and Carballo, J. (I959). Factors involved in digitalis sensitivity in chronic pulmonary insufficiency. American Heart fournal, 57, 460.

Burton, C. R. (1962). Paroxysmal atrial tachycardia with atrioventricular block. Canadian Medical Association fournal, 87, 114.

Chung, E. K. (1970). Digitalis-induced cardiac arrhythmias. American Heart fournal, 79, 845.

Crouch, R. B., Herrmann, G. R., and Hejtmancik, M. R. (1956). Digitalis intoxication. Texas State Fournal of Medicine, 52, 714.

Dreifus, L. S., McKnight, E. H., Katz, M., and Likoff, W. (1963). Digitalis intolerance. Geriatrics, 18, 494.

Dubnow, M. H., and Burchell, H. B. (1965). A comparison of digitalis intoxication in two separate periods. Annals of Internal Medicine, 62, 956.
El-Sherif, N. (1970). Supraventricular tachycardia with AV block. British Heart fournal, 32, 46.

Flaxman, N. (1948). Digitoxin poisoning: report of 30 cases. American fournal of the Medical Sciences, 216, 179.

Freiermuth, L. J., and Jick, S. (1958). Paroxysmal atrial tachycardia with atrioventricular block. American fournal of Cardiology, I, 584 .

Goldberg, L. M., Bristow, J. D., Parker, B. M., and Ritzmann, L. W. (1960). Paroxysmal atrial tachycardia with atrioventricular block, its frequent association with chronic pulmonary disease. Circulation, 21, 499.

Harris, E. A., Julian, D. G., and Oliver, M. F. (1960). Atrial tachycardia with atrioventricular block due to digitalis poisoning. British Medical fournal, 2, 1409.

Hejtmancik, M. R., Herrmann, G. R., and Wright, J. C. (1958). Paroxysmal supraventricular tachycardias complicating organic heart disease. American Heart fournal, 56, 671.

Herrmann, G. R., Decherd, G. M., Jr., and McKinlay, W. F. (1944). Digitalis poisoning. Fournal of the American Medical Association, 126, 760.

Heyl, A. F. (1932). Auricular paroxysmal tachycardia caused by digitalis: report of a case. Annals of Internal Medicine, 5, 858 .

Lewis, T. (1909). Paroxysmal tachycardia. Heart, $\mathbf{x}$, 43.

Lown, B., and Levine, S. A. (1954). Current concepts in digitalis therapy. New England fournal of Medicine, 250, 819.

Lown, B., and Levine, H. D. (1958). Atrial Arrhythmias, Digitalis and Potassium. Landsberger Medical Books, New York.

Lown, B., Wyatt, N. F., and Levine, H. D. (1960). Paroxysmal atrial tachycardia with block. Circulation, 21, 129.

Mackenzie, J. (I91 I). Digitalis. Heart, 2, 273.

Nadas, A. S., Rudolph, A. M., and Reinhold, J. D. L. (I953). The use of digitalis in infants and children. A clinical study of patients in congestive heart failure. New England fournal of Medicine, 248, 98.

Oram, S., Resnekov, L., and Davies, P. (1960). Digitalis as a cause of paroxysmal atrial tachycardia with atrioventricular block. British Medical fournal, 2, 1402 .

Phillips, J. H., Sumner, R. G., Johnson, C. D., and Higgins, T. G. (1966). A study of the ventriculophasic phenomenon in paroxysmal atrial tachycardia with block. Diseases of the Chest, 50, 40.

Rodensky, P. L., and Wasserman, F. (I961). Observations on digitalis intoxication. Archives of Internal Medicine, 108, 171 .

Rosenbaum, M. B., and Lepeschkin, E. (1955). The effect of ventricular systole on auricular rhythm in auriculoventricular block. Circulation, 11, 240.

Shrager, M. W. (1957). Digitalis intoxication: a review and report of 40 cases with emphasis on aetiology. Archives of Internal Medicine, 100, 881.

Simonson, E., and Berman, R. (I95I). Differentiation between paroxysmal auricular tachycardia with partial A-V block and auricular flutter. American Heart fournal, 42, 387.

von Capeller, D., Copeland, G. D., and Stern, T. N. (1959). Digitalis intoxication: a clinical report of 148 cases. Annals of Internal Medicine, 50, 869.

Wahi, P. L., Bhargava, K. C., Singh, R., and Khattri, H. N. (1966). Paroxysmal atrial tachycardia with block. Indian Heart fournal, 18, 383.

Requests for reprints to Professor B. L. Agarwal, 4 Professor's Bungalow, Medical College Enclave, Allahabad, India. 